\title{
PRESERVATION OF NORMAL HUMAN PLASMA IN THE LIQUID STATE. I. A STATISTICAL STUDY OF 1751 ADMINISTRATIONS ${ }^{1}$
}

\author{
BY EUGENE L. LOZNER 2 AND LLOYD R. NEWHOUSER * \\ (From the Naval Medical Research Institute and the Naval Medical School, National Naval Medical \\ Center, Bethesda, Maryland)
}

(Received for publication November 29, 1943)

Of all the blood derivatives in use at present, plasma preserved in the liquid state is the simplest and most economical to prepare. It requires neither constant refrigeration, as does frozen plasma, nor an expensive desiccating set-up, as does dried plasma. Preservation in the liquid state has, however, certain distinct disadvantages. Probably the most important of these is the fact that relatively slight accidental bacterial contaminations during preparation may multiply to dangerous proportions during preservation. Others are the decrease in physiologic activity of labile constituents such as prothrombin, complement, and isohemagglutinins, studies on which are presented in the following papers $(1,2)$, the tendency of fibrinogen to precipitate out on storage, particularly at temperatures below $15^{\circ} \mathrm{C}$., and the denaturation of proteins by temperatures above $37^{\circ} \mathrm{C}$. It is chiefly the possibility of bacterial contamination, however, which has caused several authorities to advise against preservation of plasma in the liquid state (3).

For the past three years, the Plasma Department of the U.S. Naval Medical School has prepared plasma, preserved it in the liquid state, and distributed it to Naval Medical Activities within continental limits. It is the purpose of this communication to present a statistical study of the first 1751 complete reports of administrations of this plasma. It is proposed by this presentation to demonstrate that when normal human plasma is prepared by a closed system with scrupulously aseptic technique, and administered

1 This article has been released for publication by the Division of Publications of the Bureau of Medicine and Surgery of the U. S. Navy. The opinions and views set forth in this article are those of the writers and are not to be considered as reflecting the policies of the Navy Department.

'Lieutenant, Medical Corps, United States Naval Reserve.

- Captain, Medical Corps, United States Navy. with suitable precautions, particularly with regard to filtration, it may be preserved in the liquid state for periods up to at least $\mathbf{1 5}$ months and transfused into patients with safety and benefit. Certain other aspects of plasma administration such as analyses of dosage, indications, and untoward reactions will also be presented.

\section{METHODS}

All the plasma administered in this study was prepared by the "closed vacuum" technique as described elsewhere $(4,5)$. In all lots, 50 per cent glucose and 1 per cent sodium ethyl mercuric thiosalicylate (merthiolate) were added so as to produce a final concentration of 5 per cent and $1: 10,000$ respectively. In the first 135 lots, the plasma was unpooled. In subsequent lots, the plasma from between 5 and 12 donors was pooled. The majority of the plasma was stored at room temperature throughout the study. This temperature ranged between $16^{\circ}$ and $\cdot 37^{\circ} \mathrm{C}$. A small fraction was kept between $12^{\circ}$ and $20^{\circ} \mathrm{C}$. during the summer of 1941 . The donors were all recruited by the District of Columbia Red Cross Volunteer Blood Donor Service and bled at the Army-Navy Blood Donor Center, Washington, D. C. The donors were asked to refrain from eating fatty foods for 6 hours previous to blood donation. The plasma was prepared in a laboratory located in the same building as the donor center. Plasma was issued by messenger, railway express, and air express to all continental Naval Medical Activities requiring plasma, upon request from these activities. Their geographic location ranged from Miami Air Station, Florida, to Bremerton Navy Yard, Washington. With the exception of the following instructions on the label of every bottle, no control was exercised over the administration of the plasma: "1. A filter must be used in the intravenous set. 2. Do not apply heat to plasma at any time, or to the intravenous equipment during administration. 3. Except in severe secondary shock, the rate of administration should not exceed $10 \mathrm{cc}$. per minute. 4. Plasma has a tendency to form a precipitate upon standing. This does not affect the safety or efficiency of the plasma." Every bottle was accompanied by a detailed questionnaire ${ }^{4}$ for the collection of the information upon which this study is based. After February 1942, each shipment of plasma was accompanied by the instruction that it be stored at room temperature.

\footnotetext{
- Space does not permit the inclusion of this questionnaire herein. It is available on application to the authors.
} 
A code for transposition of the questionnaire to punch cards was drawn up. By means of an 80 column punch card, it was possible to code 19 items. Coding of all items involving a medical opinion such as indication or reaction was done by one of us (E.L.L.). Upon completion and proof-reading of the coding, punch card tabulations and counts and statistical analyses thereof were made by the Division of Vital Statistics, Bureau of Medicine and Surgery, Navy Department. All the data presented, therefore, are the results of questionnaire analysis.

\section{RESULTS}

A total of 516,140 cc. of citrated plasma was administered in this study to a total of 726 patients, giving an average dose in each administration of $295 \mathrm{cc}$. and an average amount given each patient of $711 \mathrm{cc}$. The upper limit of consecutive dosage to any individual was $3000 \mathrm{cc}$. and of total dosage was $12,600 \mathrm{cc}$. The distribution of total dosage is presented in Table I. It will be seen that because of the use of $250 \mathrm{cc}$. of plasma as the "unit" of dosage, the peak of the distribution comes between 200 and 299 cc. with a secondary peak between 500 and 599 cc. Similarly, Table II presents the distribution of number of administrations showing that approximately half the group required 2 or more

TABLE I

Total volume of plasma received by each patient

\begin{tabular}{|c|c|c|c|}
\hline Volume & $\begin{array}{c}\text { Number } \\
\text { of } \\
\text { patients }\end{array}$ & Volume & $\begin{array}{c}\text { Number } \\
\text { of } \\
\text { patients }\end{array}$ \\
\hline \multirow[t]{2}{*}{$\begin{array}{l}\text { cc. } \\
100 \text { to } 199 \\
200 \text { to } 299 \\
300 \text { to } 399 \\
400 \text { to } 499 \\
500 \text { to } 599 \\
600 \text { to } 699 \\
700 \text { to } 799 \\
800 \text { to } 899 \\
900 \text { to } 999 \\
1000 \text { to } 1099 \\
1100 \text { to } 1199 \\
1200 \text { to } 1299 \\
1300 \text { to } 1399 \\
1400 \text { to } 1499 \\
1500 \text { to } 1599 \\
1600 \text { to } 1699 \\
1700 \text { to } 1799 \\
1800 \text { to } 1899 \\
2000 \text { to } 2099 \\
2100 \text { to } 2199 \\
2200 \text { to } 2299 \\
2300 \text { to } 2399 \\
2400 \text { to } 2499\end{array}$} & $\begin{array}{r}7 \\
246 \\
44 \\
64 \\
155 \\
12 \\
37 \\
22 \\
21 \\
28 \\
4 \\
12 \\
6 \\
3 \\
10 \\
4 \\
4 \\
7 \\
5 \\
2 \\
2 \\
2 \\
2\end{array}$ & $\begin{array}{r}\text { cc. } \\
2500 \text { to } 2599 \\
2600 \text { to } 2699 \\
2700 \text { to } 2799 \\
2800 \text { to } 2899 \\
2900 \text { to } 2999 \\
3000 \text { to } 3099 \\
3100 \text { to } 3199 \\
3400 \text { to } 3499 \\
3600 \text { to } 3699 \\
3700 \text { to } 3799 \\
4000 \text { to } 4099 \\
4100 \text { to } 4199 \\
4500 \text { to } 4599 \\
4800 \text { to } 4899 \\
5000 \text { to } 5099 \\
5100 \text { to } 5199 \\
5200 \text { to } 5299 \\
6300 \text { to } 6399 \\
7000 \text { to } 7099 \\
7800 \text { to } 7899 \\
10,400 \text { to } 10,499 \\
12,600 \text { to } 12,699\end{array}$ & $\begin{array}{l}1 \\
2 \\
1 \\
2 \\
1 \\
2 \\
1 \\
1 \\
1 \\
1 \\
1 \\
1 \\
2 \\
1 \\
2 \\
1 \\
1 \\
1 \\
1 \\
1 \\
1 \\
1\end{array}$ \\
\hline & & 516,140 & 726 Totals \\
\hline
\end{tabular}

TABLE II

Number of administrations received by each patient

\begin{tabular}{c|c|c|c}
\hline \hline Administrations & Patients & Administrations & Patients \\
\cline { 2 - 3 } & 385 & 11 & 2 \\
2 & 174 & 12 & 4 \\
3 & 60 & 14 & 1 \\
4 & 33 & 15 & 2 \\
5 & 21 & 16 & 1 \\
6 & 12 & 18 & 1 \\
7 & 6 & 20 & 4 \\
8 & 6 & 21 & 1 \\
9 & 5 & 34 & 1 \\
10 & 6 & 50 & 1 \\
\hline & & 1751 & 726 Totals \\
\hline
\end{tabular}

injections and 15 per cent required 4 or more injections.

Table III presents the distribution of indications for administration and the therapeutic results reported in each. It will be observed that the most frequent indication was hypoproteinemia and the next most frequent was

TABLE III

Clinical indication for administration and the therapeutic result reported

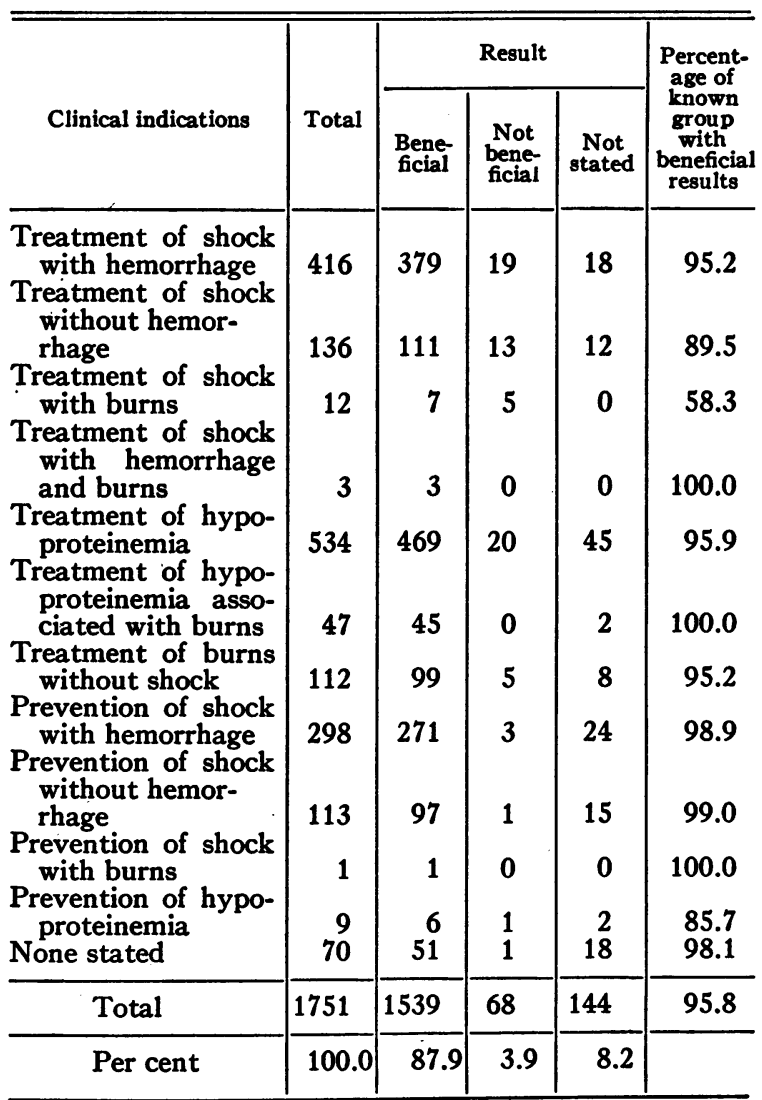


TABLE IV

Time of day plasma was administered

\begin{tabular}{ccc}
\hline \hline Time & Number & Per cent * \\
\hline Midnight to 8:00 a.m. & 144 & 8.8 \\
8:01 a.m. to 4:00 p.m. & 1094 & 67.3 \\
4:01 p.m. to Midnight & 388 & 23.9 \\
Not stated & 125 & \\
Total & 1751 & 100.0 \\
\hline
\end{tabular}

* Omitting the group which did not state the time of administration.

shock in association with hemorrhage. It is of interest that almost one-fourth of the administrations were performed for reasons relating to the prevention of shock. Of the total groups of those in which a therapeutic result was reported, almost 96 per cent of the questionnaires stated the administration to be beneficial. It may be

TABLE $V$

Distribution of administrations according to age of plasma and relationship to untoward reactions

\begin{tabular}{|c|c|c|c|c|c|c|c|}
\hline \multirow{2}{*}{$\begin{array}{c}\begin{array}{c}\text { Age } \\
\text { of } \\
\text { plasma }\end{array} \\
\text { months }\end{array}$} & \multicolumn{2}{|c|}{ Total } & \multicolumn{2}{|c|}{ Reactions } & \multicolumn{2}{|c|}{ No Reaction } & \multirow{2}{*}{$\begin{array}{c}\begin{array}{c}\text { Reactions } \\
\text { in each } \\
\text { age group }\end{array} \\
\text { per cent }\end{array}$} \\
\hline & $\begin{array}{c}\text { num- } \\
\text { ber }\end{array}$ & $\begin{array}{l}\text { per } \\
\text { cent }\end{array}$ & $\underset{\text { ber }}{\text { num- }}$ & $\begin{array}{l}\text { per } \\
\text { cent }\end{array}$ & $\underset{\text { ber }}{\text { num- }}$ & $\begin{array}{l}\text { per } \\
\text { cent }\end{array}$ & \\
\hline $\begin{array}{r}0 \text { to } 0.9 \\
1 \text { to } 1.9 \\
2 \text { to } 2.9 \\
3 \text { to } 3.9 \\
4 \text { to } 4.9 \\
5 \text { to } 5.9 \\
6 \text { to } 6.9 \\
7 \text { to } 7.9 \\
8 \text { to } 8.9 \\
9 \text { to } 9.9 \\
10 \text { to } 10.9 \\
11 \text { to } 11.9 \\
12 \text { to } 12.9 \\
13 \text { to } 13.9 \\
14 \text { to } 14.9 \\
15 \text { to } 15.9\end{array}$ & $\begin{array}{r}37 \\
226 \\
238 \\
263 \\
219 \\
223 \\
168 \\
142 \\
51 \\
32 \\
46 \\
50 \\
23 \\
22 \\
9 \\
2\end{array}$ & $\begin{array}{r}2.1 \\
12.9 \\
13.6 \\
15.0 \\
12.5 \\
12.7 \\
9.6 \\
8.1 \\
2.9 \\
1.9 \\
2.6 \\
2.9 \\
1.3 \\
1.3 \\
0.5 \\
0.1\end{array}$ & $\begin{array}{r}4 \\
14 \\
10 \\
15 \\
8 \\
5 \\
7 \\
7 \\
0 \\
0 \\
2 \\
0 \\
0 \\
0 \\
0 \\
0\end{array}$ & $\begin{array}{r}5.6 \\
19.4 \\
13.9 \\
20.8 \\
11.1 \\
6.9 \\
9.7 \\
9.7 \\
0.0 \\
0.0 \\
2.8 \\
0.0 \\
0.0 \\
0.0 \\
0.0 \\
0.0\end{array}$ & $\begin{array}{r}33 \\
213 \\
228 \\
248 \\
210 \\
216 \\
164 \\
134 \\
51 \\
32 \\
44 \\
50 \\
23 \\
22 \\
9 \\
2\end{array}$ & $\begin{array}{r}2.0 \\
12.7 \\
13.6 \\
14.8 \\
12.5 \\
12.9 \\
9.8 \\
8.0 \\
3.0 \\
1.9 \\
2.6 \\
3.0 \\
1.4 \\
1.3 \\
0.5 \\
0.1\end{array}$ & $\begin{array}{r}10.8 \\
6.2 \\
4.2 \\
5.7 \\
3.7 \\
2.2 \\
4.2 \\
4.9 \\
0.0 \\
0.0 \\
4.3 \\
0.0 \\
0.0 \\
0.0 \\
0.0 \\
0.0\end{array}$ \\
\hline Totals & 1751 & 99.9 & 72 & 100.1 & 1679 & 100.1 & 4.1 \\
\hline
\end{tabular}

Statistical evaluation

\begin{tabular}{l|c|c|c}
\hline & \multirow{2}{*}{$\begin{array}{c}\text { Mean age } \\
\text { of plasma }\end{array}$} & \multicolumn{2}{|c}{ Standard deviation } \\
\cline { 2 - 4 } & & Distribution & Mean \\
\hline & months & \multicolumn{3}{|c}{ months } \\
Total & 5.02 & 2.98 & 0.07 \\
Reactions & 3.93 & 2.33 & 0.27 \\
No reaction & 5.06 & 3.01 & 0.07 \\
\hline
\end{tabular}

The difference in age of plasma between that causing reactions and that causing no reaction is 1.1 months. The standard deviation of the difference is 0.28 months. $\frac{1.1}{0.28}=3.9$. Therefore, the plasma causing reactions is significantly younger than that causing no reaction. of significance that 8 per cent of the total group did not indicate any therapeutic result.

Table IV presents the distribution of administrations with respect to time of day. It will be observed that in this series, the nature of which has been previously defined, 67 per cent of the administrations were performed during the classical working day and only 9 per cent were performed between midnight and 8 a.m. Thus, in this series the administration of plasma would usually appear to be a procedure which one might classify as elective.

An intensive study was made of the administrations which were reported as being followed by untoward reactions. Some of the data concerning these administrations are presented in Tables V, VI, VII, VIII, and IX.

Seventy-two reactions in all were reported or an incidence of 4.1 per cent. Fifty-one were described as mild, 18 moderate, and 3 severe. Forty-nine were pyrogenic in type, i.e., chills and/or fever, 13 urticarial, and 10 miscellaneous in character.

TABLE VI

Distribution of administrations according to hospitals and relationship to untoward reactions

\begin{tabular}{c|c|c|c}
\hline \hline \multirow{2}{*}{ Hospital number } & Administrations & Reactions & Reactions \\
\cline { 2 - 3 } 1 & & number & per cent \\
2 & 55 & 2 & 3.6 \\
3 & 70 & 3 & 4.3 \\
4 & 1 & 0 & 0.0 \\
5 & 150 & 14 & 9.3 \\
6 & 215 & 12 & 5.6 \\
7 & 9 & 0 & 0.0 \\
8 & 326 & 14 & 4.3 \\
9 & 33 & 0 & 0.0 \\
10 & 12 & 0 & 0.0 \\
11 & 398 & 12 & 3.0 \\
12 & 16 & 2 & 12.5 \\
13 & 11 & 0 & 0.0 \\
14 & 21 & 1 & 4.8 \\
15 & 3 & 1 & 33.3 \\
16 & 17 & 0 & 0.0 \\
17 & 75 & 1 & 1.3 \\
18 & 53 & 2 & 3.8 \\
19 & 27 & 1 & 3.7 \\
20 & 10 & 0 & 0.0 \\
21 & 11 & 1 & 9.1 \\
22 & 2 & 0 & 0.0 \\
23 & 2 & 0 & 0.0 \\
24 & 45 & 0 & 0.0 \\
25 & 144 & 1 & 0.7 \\
26 & 19 & 0 & 0.0 \\
27 & 4 & 0 & 0.0 \\
28 & 15 & 2 & 28.6 \\
Totals & 1751 & 3 & 20.0 \\
\hline & & 72 & 4.1 \\
\hline & & &
\end{tabular}


TABLE VII

Relationship of untoward reactions to clinical indication and distribution of types of untoward reactions

\begin{tabular}{|c|c|c|c|c|c|c|c|c|c|c|c|c|}
\hline \multirow[b]{2}{*}{ Indication } & \multirow[b]{2}{*}{ Total } & \multicolumn{11}{|c|}{ Type of reaction } \\
\hline & & 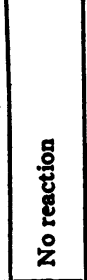 & 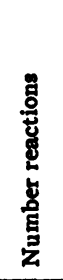 & 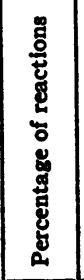 & 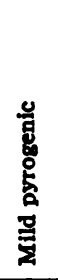 & 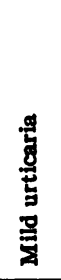 & 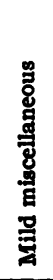 & 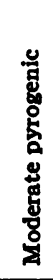 & 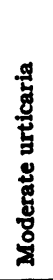 & 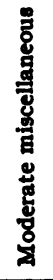 & 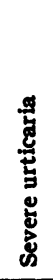 & 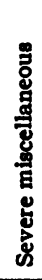 \\
\hline Total & 1751 & 1679 & 72 & 4.1 & 37 & 8 & 6 & 12 & 4 & 2 & 1 & 2 \\
\hline $\begin{array}{l}\text { Treatment of shock with hemorrhage } \\
\text { Treatment of shock without hemorrhage } \\
\text { Treatment of shock with burns } \\
\text { Treatment of shock with hemorrhage and burns } \\
\text { Treatment of hypoproteinemia } \\
\text { Treatment of hypoproteinemia associated with } \\
\text { burns } \\
\text { Treatment of burns without shock } \\
\text { Prevention of shock with hemorrhage } \\
\text { Prevention of shock without hemorrhage } \\
\text { Prevention of shock with burns } \\
\text { Prevention of hypoproteinemia } \\
\text { No apparent indication }\end{array}$ & $\begin{array}{r}417 \\
136 \\
12 \\
3 \\
534 \\
48 \\
110 \\
298 \\
113 \\
1 \\
9 \\
70\end{array}$ & $\begin{array}{r}405 \\
131 \\
12 \\
3 \\
511 \\
45 \\
105 \\
283 \\
108 \\
1 \\
6 \\
69\end{array}$ & $\begin{array}{r}12 \\
5 \\
0 \\
0 \\
23 \\
3 \\
5 \\
5 \\
15 \\
5 \\
0 \\
3 \\
1\end{array}$ & \begin{tabular}{|l|}
2.9 \\
3.7 \\
0 \\
0 \\
4.3 \\
\\
6.3 \\
4.5 \\
5.0 \\
4.4 \\
0 \\
33.3 \\
1.4
\end{tabular} & $\begin{array}{r}6 \\
4 \\
0 \\
0 \\
10 \\
2 \\
2 \\
10 \\
3 \\
0 \\
0 \\
0\end{array}$ & $\begin{array}{l}1 \\
1 \\
0 \\
0 \\
1 \\
1 \\
0 \\
2 \\
1 \\
0 \\
1 \\
0\end{array}$ & $\begin{array}{l}1 \\
0 \\
0 \\
0 \\
3 \\
\\
0 \\
0 \\
1 \\
0 \\
0 \\
0 \\
1\end{array}$ & $\begin{array}{l}1 \\
0 \\
0 \\
0 \\
5 \\
\\
0 \\
2 \\
1 \\
1 \\
0 \\
2 \\
0\end{array}$ & $\begin{array}{l}2 \\
0 \\
0 \\
0 \\
0 \\
0 \\
1 \\
1 \\
0 \\
0 \\
0 \\
0\end{array}$ & $\begin{array}{l}1 \\
0 \\
0 \\
0 \\
1 \\
0 \\
0 \\
0 \\
0 \\
0 \\
0 \\
0\end{array}$ & $\begin{array}{l}0 \\
0 \\
0 \\
0 \\
1 \\
\\
0 \\
0 \\
0 \\
0 \\
0 \\
0 \\
0\end{array}$ & $\begin{array}{l}0 \\
0 \\
0 \\
0 \\
2 \\
\\
0 \\
0 \\
0 \\
0 \\
0 \\
0 \\
0\end{array}$ \\
\hline
\end{tabular}

TABLE VIII

Relationship of untoward reactions to rate of injection

\begin{tabular}{ccc}
\hline \hline Rate of injection & Reactions & No reaction \\
\hline cc. per minute & & \\
1 to 1.9 & 0 & 5 \\
2 to 2.9 & 5 & 17 \\
3 to 3.9 & 10 & 19 \\
4 to 4.9 & 12 & 38 \\
5 to 5.9 & 5 & 25 \\
6 to 6.9 & 1 & 28 \\
7 to 7.9 & 3 & 14 \\
8 to 8.9 & 7 & 36 \\
9 to 9.9 & 2 & 12 \\
10 to 10.9 & 5 & 18 \\
12 to 12.9 & 2 & 8 \\
13 to 13.9 & 1 & 6 \\
15 to 15.9 & 1 & 1 \\
16 to 16.9 & 3 & 8 \\
17 to 17.9 & 0 & 1 \\
18 to 18.9 & 5 & 1 \\
20 to 20.9 & 0 & 1 \\
22 to 22.9 & 0 & 1 \\
25 to 25.9 & 0 & 1 \\
\hline
\end{tabular}

* Ten did not state time of injection.

Statistical evaluation

\begin{tabular}{|c|c|c|c|}
\hline \multirow[b]{3}{*}{$\begin{array}{l}\text { Reactions } \\
\text { No reaction }\end{array}$} & \multirow{3}{*}{$\begin{array}{c}\text { Mean } \\
c c . \text { per minute } \\
7.82 \\
7.31\end{array}$} & \multicolumn{2}{|c|}{$\begin{array}{c}\text { Standard deviation } \\
\text { Distribution }\end{array}$} \\
\hline & & \multicolumn{2}{|c|}{ cc. per minute } \\
\hline & & $\begin{array}{l}4.87 \\
3.91\end{array}$ & $\begin{array}{l}0.62 \\
0.25\end{array}$ \\
\hline
\end{tabular}

There is no statistically significant difference between the rate of injection of the plasma causing reactions and that causing no reaction.
Table $\mathrm{V}$ presents the relationship of age of preservation to the incidence of untoward reactions. It appears to be statistically significant in this series that the younger plasma is followed by reactions more often than the older plasma. In 744 administrations of plasma under 4 months old, there were 42 or 5.6 per cent reactions. In 1007 administrations over 4 months old, there were 30 or 3.0 per cent reactions. In 545 administrations over 6 months old, there were 14 or 2.6 per cent reactions. In 235 administrations over 8 months old, there were 2 or 0.9 per cent reactions.

Table VI presents the relationship of untoward reactions to the hospital concerned. This appears to be another significant factor in the production of untoward reactions. The reaction rate for various activities ranged from 0.0 to 33.3 per cent.

Table VII presents the relationship of untoward reactions to indication for administration. There does not appear to be any relationship except for a lower incidence (3.0 per cent) of reactions among those conditions in which shock was present than in those in which shock was absent (4.7 per cent).

Table VIII presents the relationship between rate of injection and appearance of untoward 
reaction. Within the limits of this study, there did not appear to be any relationship.

In view of the fact that most of the plasma administered in this study was pooled, it was felt that the reactions could be divided into those possibly "attributable" to plasma and those probably "not attributable" to plasma, depending on whether or not other administrations from the same pool were satisfactory. It was decided arbitrarily that if two or more other administrations from the same pool were satisfactory, the reaction from a given administration was probably not "attributable" to the plasma. Table IX presents the results of this analysis. It will be observed that 52 of the 72 reactions fall into the group probably "not attributable" to the plasma. Thus, on this basis, only 1.1 per cent of the administrations could be said to be followed by reactions possibly "attributable" to the plasma.

Nine pools gave reactions on 2 administrations. No pool gave reactions on more than 2 administrations. Six of the 9 fell into the group probably "not attributable" to plasma as 2 or more other administrations from the same pool were

TABLE IX-A

Analysis of the untoward reactions with respect to "attributability" to plasma

\begin{tabular}{|c|c|c|c|c|}
\hline \multicolumn{5}{|c|}{ Possibly "attributable" to plasma } \\
\hline Number & Lot number & $\begin{array}{l}\text { Other } \\
\text { adminis- } \\
\text { trations } \\
\text { from } \\
\text { same lot }\end{array}$ & $\begin{array}{l}\text { Other satis- } \\
\text { factory } \\
\text { administra- } \\
\text { tions from } \\
\text { same lot }\end{array}$ & Type* \\
\hline $\begin{array}{r}1 \\
2 \\
3 \\
4 \\
5 \\
6 \\
7 \\
8 \\
9 \\
10 \\
11 \\
12 \\
13 \\
14 \\
15 \\
16 \\
17 \\
18 \\
19 \\
20\end{array}$ & $\begin{array}{c}23 \\
84 \\
119 \\
261.1 \\
261.2 \\
331.1 \\
333.3 \\
367.7 \\
441.5 \\
482.7 \\
507.7 \\
596.2 \\
597.1 \\
681.6 \\
771.1 \\
771.5 \\
863.5 \\
882.7 \\
1326.3 \\
875.5\end{array}$ & $\begin{array}{l}0 \\
0 \\
0 \\
1 \\
1 \\
1 \\
1 \\
1 \\
1 \\
0 \\
0 \\
1 \\
1 \\
0 \\
1 \\
1 \\
0 \\
0 \\
0 \\
1\end{array}$ & $\begin{array}{l}\mathbf{0} \\
0 \\
0 \\
0 \\
0 \\
0 \\
0 \\
1 \\
1 \\
0 \\
0 \\
1 \\
1 \\
0 \\
0 \\
0 \\
0 \\
0 \\
0 \\
1\end{array}$ & $\begin{array}{l}\mathbf{P} \\
\mathbf{U} \\
\mathbf{P} \\
\mathbf{M} \\
\mathbf{M} \\
\mathbf{P} \\
\mathbf{P} \\
\mathbf{P} \\
\mathbf{M} \\
\mathbf{U} \\
\mathbf{M} \\
\mathbf{P} \\
\mathbf{P} \\
\mathbf{U} \\
\mathbf{P} \\
\mathbf{P} \\
\mathbf{P} \\
\mathbf{P} \\
\mathbf{P} \\
\mathbf{P}\end{array}$ \\
\hline
\end{tabular}

* $\mathbf{P}=$ Pyrogenic, i.e., chills and/or fever

$\mathrm{U}=$ Urticarial

$\mathbf{M}=$ Miscellaneous.
TABLE IX-B

Analysis of the untoward reactions with respect to "attributability" to plasma

\begin{tabular}{|c|c|c|c|c|}
\hline \multicolumn{5}{|c|}{ Probably "not attributable" to plasma } \\
\hline Number & Lot number & $\begin{array}{l}\text { Other } \\
\text { adminis- } \\
\text { trations } \\
\text { from } \\
\text { same lot }\end{array}$ & $\begin{array}{l}\text { Other satis- } \\
\text { factory } \\
\text { administra- } \\
\text { tions from } \\
\text { same lot }\end{array}$ & Type* \\
\hline $\begin{array}{l}1 \\
2 \\
3 \\
4 \\
5 \\
6 \\
7 \\
8 \\
9 \\
10 \\
11 \\
12 \\
13 \\
14 \\
15 \\
16 \\
17 \\
18 \\
19 \\
20 \\
21 \\
22 \\
23 \\
24 \\
25 \\
26 \\
27 \\
28 \\
29 \\
30 \\
31 \\
32 \\
33 \\
34 \\
35 \\
36 \\
37 \\
38 \\
39 \\
40 \\
41 \\
42 \\
43 \\
44 \\
45 \\
46 \\
47 \\
48 \\
49 \\
50 \\
51 \\
52\end{array}$ & $\begin{array}{r}139.1 \\
139.2 \\
157.5 \\
159.2 \\
162.3 \\
172.5 \\
173.6 \\
174.1 \\
175.4 \\
181.7 \\
182.4 \\
182.7 \\
183.3 \\
200.4 \\
200.5 \\
205.5 \\
208.5 \\
215.7 \\
220.5 \\
222.3 \\
228.4 \\
228.5 \\
263.5 \\
302.1 \\
309.1 \\
314.2 \\
315.2 \\
342.4 \\
343.2 \\
373.6 \\
375.1 \\
375.2 \\
377.6 \\
381.4 \\
388.1 \\
393.3 \\
452.1 \\
456.2 \\
521.6 \\
523.3 \\
532.6 \\
621.6 \\
769.4 \\
770.4 \\
770.6 \\
774.3 \\
1000.2 \\
1003.3 \\
1055.3 \\
1060.3 \\
1311.1 \\
1319.1\end{array}$ & $\begin{array}{l}4 \\
4 \\
5 \\
2 \\
4 \\
5 \\
5 \\
5 \\
4 \\
6 \\
6 \\
6 \\
5 \\
3 \\
3 \\
5 \\
5 \\
5 \\
4 \\
4 \\
4 \\
4 \\
6 \\
4 \\
2 \\
5 \\
4 \\
2 \\
2 \\
4 \\
4 \\
4 \\
4 \\
4 \\
5 \\
2 \\
5 \\
3 \\
5 \\
4 \\
6 \\
5 \\
4 \\
4 \\
4 \\
4 \\
3 \\
3 \\
3 \\
3 \\
3 \\
2\end{array}$ & $\begin{array}{l}3 \\
3 \\
5 \\
2 \\
4 \\
5 \\
5 \\
5 \\
4 \\
6 \\
5 \\
5 \\
5 \\
2 \\
2 \\
5 \\
5 \\
2 \\
4 \\
4 \\
3 \\
3 \\
6 \\
4 \\
2 \\
5 \\
4 \\
2 \\
2 \\
4 \\
3 \\
3 \\
4 \\
4 \\
5 \\
2 \\
5 \\
3 \\
5 \\
4 \\
6 \\
5 \\
4 \\
3 \\
3 \\
4 \\
3 \\
3 \\
3 \\
3 \\
3 \\
2\end{array}$ & $\begin{array}{l}\mathbf{M} \\
\mathbf{P} \\
\mathbf{U} \\
\mathbf{U} \\
\mathbf{M} \\
\mathbf{P} \\
\mathbf{U} \\
\mathbf{P} \\
\mathbf{P} \\
\mathbf{P} \\
\mathbf{P} \\
\mathbf{P} \\
\mathbf{P} \\
\mathbf{P} \\
\mathbf{P} \\
\mathbf{M} \\
\mathbf{U} \\
\mathbf{P} \\
\mathbf{M} \\
\mathbf{U} \\
\mathbf{P} \\
\mathbf{P} \\
\mathbf{P} \\
\mathbf{P} \\
\mathbf{P} \\
\mathbf{M} \\
\mathbf{U} \\
\mathbf{U} \\
\mathbf{P} \\
\mathbf{M} \\
\mathbf{P} \\
\mathbf{U} \\
\mathbf{P} \\
\mathbf{P} \\
\mathbf{P} \\
\mathbf{P} \\
\mathbf{U} \\
\mathbf{P} \\
\mathbf{P} \\
\mathbf{U} \\
\mathbf{P} \\
\mathbf{P} \\
\mathbf{P} \\
\mathbf{P} \\
\mathbf{P} \\
\mathbf{P} \\
\mathbf{P} \\
\mathbf{P} \\
\mathbf{P} \\
\mathbf{P} \\
\mathbf{P} \\
\mathbf{P}\end{array}$ \\
\hline
\end{tabular}

* $\mathbf{P}=$ Pyrogenic, i.e., chills and/or fever $\mathrm{U}=$ Urticarial

$\mathbf{M}=$ Miscellaneous.

satisfactory. In all 9 , both reactions were at the same hospital. Three hospitals accounted for 14 of these 18 reactions. In 3 of the 9 pools, both reactions were by the same individual on 
the same day. Of these 18 reactions, only one was urticarial in nature. Thus, no pool gave urticaria to more than one patient. Of the 13 urticarias, 10 fell into the group "not attributable" to plasma. It appears, therefore, that urticaria is more frequently the result of recipient hypersensitivity to an allergen in the plasma than of the passive transfer of an antibody in the plasma causing the recipient to react to an allergen in his environment. Three of the urticarias occurred following the administration of plasma more than 7 months old indicating that the agent responsible was rather stable.

The 72 reactions were given by 63 individuals. No patient suffered more than 2 reactions. Thus, in this series, no patient could be said to be particularly susceptible to reactions from plasma. In the 9 patients who gave 2 reactions each, only 1 instance of urticaria occurred.

Of the 72 reactions, in 45 (62 per cent), the administration was reported as beneficial, in 7 (10 per cent), as not beneficial, and in 20 (28 per cent), the therapeutic result was not stated.

No instance of a hemolytic reaction was reported.

\section{DISCUSSION}

The findings presented in this study, coupled with those presented in the following papers $(1,2,6)$, indicate that when plasma is prepared by a "closed" system with scrupulously aseptic technique, it may be preserved in the liquid state for many months and be administered with safety and benefit. The mean age of the plasma before administration was 5 months; 545 administrations were of plasma over 6 months old. The untoward reaction rate of this latter group was 2.6 per cent or less than half that of the group under 4 months old. In the group of 235 administrations over 8 months old, the reaction rate was 0.9 per cent. These figures appear to be statistically significant. Thus, on the basis of untoward reaction rate, it appears that we have not yet reached the upper limit for preservation of plasma in the liquid state. Most of the physiological activity of the labile constituents has completely disappeared within the first 4 months of preservation (1). Thus, after this period, one is left with a protein solution entirely satisfactory for the treatment of shock, burns, or hypoproteinemia, but unsatisfactory for the treatment of hypoprothrombinemia or infections. Since the former 3 conditions far outweigh the latter in military importance, preservation of plasma in the liquid state would be contraindicated for field use only by the limited range of temperature permissible. However, in the temperate zone, it is a satisfactory method of preservation, provided that the technique of preparation and bacteriologic control are exacting.

It is of interest to speculate upon the possible reasons for the decreased reaction rate upon prolonged storage. This phenomenon would appear to be related to the disappearance of some mildly toxic labile constituent. A comparable phenomenon has been described with respect to serum and is thought to be due to the occurrence of thrombin in fresh serum. Since most plasma contains a small amount of serum, due to small clots accidentally present in the bleeding, the same theory may be extended to explain our observations. Or it may be due to the disappearance of isohemagglutinins, as is described in a following paper (2). However, since it has not been demonstrated that the titer of isoagglutinins which occurs in blood plasma is toxic and it has been demonstrated that thrombin is toxic, the serum theory is more inviting. Still a third possibility is the "contamination" of fresh plasma by a labile pyrogen which then deteriorated on storage. At the present time, none of these theories can be absolutely proven or excluded.

The total reaction rate of 4.1 per cent is at the lower end of the range commonly observed for whole blood transfusions which varies from 1 per cent to 50 per cent (7), and was 9.7 per cent at the Mayo Clinic in 1943 (8). Undoubtedly, many of the 72 reactions reported resulted from the use of pyrogenic intravenous sets over which there was no control. Indirect evidence concerning this was obtained by virtue of the fact that most of the plasma was pooled and it was possible to determine in the case of each reaction whether or not other administrations from the same pool were satisfactory. In 52 of the 72 reactions, at least 2 other administrations from the same pool were satisfactory. It is felt, therefore, that only the remainder of the reactions, namely 1.1 per cent of the administration, 
may be "attributable" to the plasma. The urticaria percentage of 0.7 per cent, is approximately the same as that which has been reported for whole blood (7).

\section{SUMMARY AND CONCLUSIONS}

1. One thousand seven hundred and fifty-one administrations of normal human plasma preserved in the liquid state have been tabulated and analyzed by the punch card system.

2. The average age of preservation was $\mathbf{5 . 0}$ months and 545 administrations were of plasma over 6 months old.

3. The total number of untoward reactions reported was 72 . In 52 of these, at least 2 other administrations from the same pool were satisfactory. This leaves a reaction rate possibly "attributable" to plasma of 1.1 per cent.

4. Two factors appeared to influence the reaction rate significantly, the hospital concerned and the age of preservation; the longer the preservation, the fewer there actions within the limits studied. Possible reasons for the latter phenomenon are discussed.

5. It may be concluded that when normal human plasma is prepared by a closed system with scrupulously aseptic technique, and administered with suitable precautions, particularly with regard to filtration, it may be preserved in the liquid state at room temperature in the temperate zone for periods up to at least a year and administered to patients with safety and benefit.

6. It may be recommended that administrations of plasma preserved in the liquid state for more than a year be continued as there does not appear to be any contraindication to such administrations as a result of this study or any other studies to date.

The assistance of Lieutenant (jg) S. Remias, H-V(S) U.S.N.R., and Ensign M. Allen, W-V(S) U.S.N.R., in the statistical analysis, is acknowledged with thanks. Ensign E. Dochterman, W-V(S) U.S.N.R., assisted in the proofreading and editing of the punch cards and tabulations.

\section{BIBLIOGRAPHY}

1. Taylor, F. H. L., Lozner, E. L., Davidson, C. S., Tagnon, H. J., and Newhouser, L. R., Preservation of normal human plasma in the liquid state. II. Comparative in vitro studies on the physiologic activity of labile constituents of liquid and frozen plasma. J. Clin. Invest., 1944, 23, 351.

2. Lozner, E. L., and Newhouser, L. R., Preservation of normal human plasma in the liquid state. IV. Studies on isohemagglutinin titers. J. Clin. Invest., 1944, 23, 361.

3. Strumia, M. M., and McGraw, J. J., The development of plasma preparations for transfusions. Ann. Int. Med., 1941, 15, 80.

4. Newhouser, L. R., and Kendrick, D. B., Human Plasma Manual. U. S. Naval Medical School, Washington, D. C., 1941.

5. U. S. Office of Civilian Defense: A Technical Manual on Citrated Human Blood Plasma. Washington, D. C., 1942.

6. Lozner, E. L., Taylor, F. H. L., Lemish, S., Snyder, R., and Newhouser, L. R., Preservation of normal human plasma in the liquid state. III. Studies on chemical and physico-chemical changes during the second year of storage. J. Clin. Invest., 1944, 23, 357.

7. DeGowin, E. L., and Hardin, R. C., Reactions from transfusion. J.A.M.A., 1940, 115, 895.

8. Lundy, J. S., et al., Annual report for 1942 of the section on anesthesia: Including data and remarks concerning blood transfusion and the use of blood substitutes II. Proc. Staff Meet., Mayo Clin., 1943, 18, 148. 